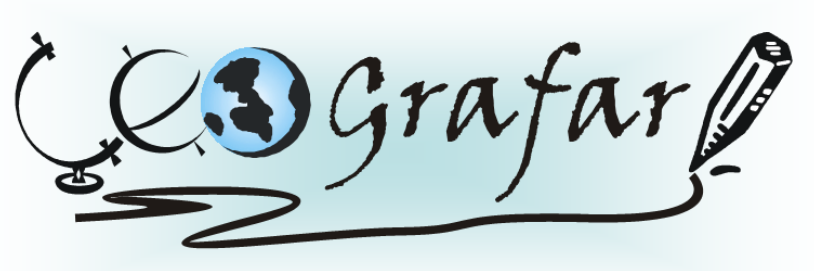

Revista Eletrônica do Programa de Pós-Graduação em Geografia - UFPR

\title{
EROSIVIDADE E ERODIBILIDADE NA BACIA HIDROGRÁFICA DO CÓRREGO JOÃO DIAS, AQUIDAUANA/MS
}

\section{EROSIVITY AND ERODIBILITY IN JOÃO DIAS CREEK RIVER BASIN, AQUIDAUANA/MS}

(Recebido em 29.05.2015; Aceito em: 11.05.2016)

\author{
Elisângela Martins de Carvalho \\ Prof $^{a}$. Dr ${ }^{\underline{a}}$ do Dep. de Geografia \\ Universidade Federal do Mato Grosso do Sul \\ Aquidauana, MS, Brasil \\ e-mail: carvalhoufms@hotmail.com \\ Emerson Figueiredo Leite \\ Prof. Dr do Dep. de Geografia \\ Universidade Federal do Mato Grosso do Sul \\ Aquidauana, MS, Brasil \\ e-mail: efleite@ufms.br
}

\begin{abstract}
RESUMO
Os processos de degradação do solo constituem grave problema em escala mundial, com consequências ambientais, sociais e econômicas significativas. São de fundamental importância estudos que avaliem a suscetibilidade dos terrenos aos processos erosivos, bem como, os fatores que influenciam nesse processo, como a quantidade e distribuição das chuvas, a declividade, o comprimento das encostas, as propriedades químicas e físicas do solo, o tipo de cobertura vegetal, e também a ação do homem, através do uso e manejo da terra. Este artigo tem como objetivo espacializar a erosividade da chuva e a erodibilidade do solo na Bacia Hidrográfica do Córrego João Dias, Aquidauana/MS, utilizando técnicas de geoprocessamento. Estas variáveis compõem a Equação Universal de Perda de Solos. Os valores de Erosividade foram obtidos através da equação descrita por Lombardi Neto; Moldenhauer, citados por Bertoni e Lombardi Neto (2008), a partir de dados de 11 pluviômetros/estações localizados na bacia e em seu entorno. Para avaliar a erodiblidade dos solos na bacia considerou-se a textura e a permeabilidade dos solos através da análise da relação textural. Os resultados demonstraram que os valores de Erosividade (Fator R) variaram de 6214 a 10955 MJ.mm/ha.h,
\end{abstract}


predominando na bacia a classe de erosividade que varia de 7800 a 8600 MJ.mm/ha.h. Quanto a erodibilidade cerca de 78,03\% da bacia apresenta a classe de erodiblidade alta, localizada no baixo, médio e alto curso da bacia. A classe de erodibilidade considerada como extremamente alta e muito alta localiza-se principalmente no alto curso, em área de nascentes.

Palavras-chave: Solos; Precipitação; Erosão; Geoprocessamento.

\begin{abstract}
The processes of soil degradation are considered a serious worldwide problem with significant environmental, social and economic consequences. Studies are essential to assess the susceptibility of land to erosion, as well as the factors that influence this process, such as the amount and distribution of rainfall, the slope, the length of the slopes, the chemical and physical properties of the soil, the vegetation type, and also the action of man, through the use and management of land. This article aimed to spatialize the rainfall erosivity and soil erodibility at João Dias creek River Basin, Aquidauna/MS, using GIS techniques. These variables compose the Universal Soil Loss Equation. Erosivity values were obtained through the equation described by Lombardi Neto; Moldenhauer, cited by Bertoni and Lombardi Neto (2008), based on data from 11 pluviometers/stations located in the basin and its surrounding area. To evaluate the soil erodibility in the river basin we considered the texture and permeability of soils through the analyses of the textural relation. The results showed that the values of erosivity ( $R$ factor) varied from 6214 to 10955 MJ.mm/ha.h, predominating the erosivity class in the basin varying from 7800 to 8600 MJ.mm/ha.h. Regarding erodibility, about $78.03 \%$ of the basin presents a class of high erodibility, located in the lower, middle and upper reaches of the basin. The erodibility class considered as extremely high and very high is located mainly in the upper river course, in the spring river area.
\end{abstract}

Keywords: Soils; Rainfall; Erosion; GIS.

\title{
INTRODUÇÃO
}

As diversas formas de uso, ocupação e manejo da terra podem acelerar os processos erosivos, tornando-se de fundamental importância estudos que avaliem a suscetibilidade dos terrenos aos processos erosivos, possibilitando manejos adequados às bacias hidrográficas.

Já mencionado por Silva (2005) os problemas advindos do uso irracional do solo, seja ele urbano ou rural, têm despertado cada vez mais o interesse de estudiosos e pesquisadores do mundo inteiro. Fato atribuído ao aumento da população mundial e a crescente demanda por alimentos. Estas pesquisas têm 
como objetivo buscar soluções para um uso mais eficiente do solo, equacionando uma maior produção com menores perdas por erosão.

A erosão do solo é um processo complexo no qual vários fatores exercem influência, de forma e magnitude variável, conforme o local de ocorrência. Silva et. all. (2004) elencam como os principais fatores, o solo, o embasamento geológico, o clima, a topografia e a cobertura do solo. A erosão é considerada o desgaste e/ou arrastamento da superfície da terra pela água corrente, vento, gelo e outros agentes geológicos.

Bigarella (2007, p. 895) enfatiza a diferença entre a erosão geológica ou natural e a acelerada ou antrópica, caracterizando a erosão geológica como "aquela que atua normalmente sem interferência do homem". Em relação à erosão acelerada o autor salienta que "desenvolve-se com taxas muito incrementadas quando comparadas àquelas da erosão normal. Inicia-se muitas vezes de forma muito lenta, passando a sofrer interferências posteriores que aceleram o processo".

Guerra e Mendonça (2004) explicam que é a ação do homem através do uso e manejo da terra que, na maioria das vezes, tende a acelerar os processos erosivos. É destacado pelos autores que a erosão dos solos tem causas relacionadas a outros fatores como a quantidade e distribuição das chuvas, a declividade, o comprimento e forma das encostas, as propriedades químicas e físicas do solo, o tipo de cobertura vegetal.

No Brasil, a erosão hídrica é a mais importante, Lepsch (2002) esclarece que seu processo ocorre por desagregação e transporte. A desagregação ocorre no impacto direto ao solo das gotas da chuva e pelas águas que escorrem na sua superfície. Em ambos os casos é a energia que atua.

Guerra (2005, p.18) ressalta que é o splash, ou a erosão de salpicamento, é o estágio inicial do processo erosivo. Neste momento há uma preparação do solo para a erosão. Essa preparação se dá pela ruptura dos agregados e pela ação transportadora que o salpicamento provoca. No processo, os agregados vão preenchendo os poros da superfície do solo, provocando a selagem e a consequente diminuição da porosidade, o que aumenta o escoamento das águas.

Deve-se considerar que a ação erosiva tem relação direta com a distribuição pluviométrica, mais ou menos regular, no tempo e no espaço, e sua intensidade (Salomão, 2005). 
Deve ser apontado ainda que o processo erosivo não ocorre da mesma forma em solos com diferentes propriedades. O comportamento de um solo frente à ação das águas varia principalmente em função de sua permeabilidade, estrutura, densidade e textura, que definem o grau de erodibilidade do solo. Estas características conferem maior ou menor resistência das partículas do solo à desagregação e capacidade de absorver e infiltrar água pluvial, aumentando o limite para início do escoamento pluvial (BERTONI; LOMBARDI NETO, 2008).

A matéria orgânica tem um papel importante na estabilidade dos agregados de solo. O problema, de acordo com Mafra (2005) consiste na eliminação da capa superficial do solo, importante por seu conteúdo em matéria orgânica e frações minerais finas. Sem esta camada superficial, explica Guerra (1995), não só a fertilidade natural do solo é afetada, mas também diminui a resistência do solo ao impacto das gotas de chuva, resultando, quase sempre, em aumento das taxas de escoamento superficial.

A avaliação do potencial de erosão laminar tem um papel fundamental enquanto contribuição ao ordenamento do uso do solo em bacias hidrográficas. Um dos métodos mais conhecidos e utilizados de simulação, predição e quantificação da erosão hídrica é o modelo matemático EUPS - Equação Universal de Perda de Solo.

Conforme proposto por WISCHMEIER; SMITH (1978) citado por Bertoni; Lombardi Neto (2008, p. 250), no modelo EUPS (Equação 1), a perda anual de solo em toneladas por hectare $(A)$ é expressa por:

$$
A=R K L S C P \text {, onde: (Equação 1) }
$$

$A=$ perda de solo calculada por unidade de área, $t / h a ;$

$R=$ fator chuva: índice de erosão pela chuva, (MJ/ha.mm/ha)

$\mathrm{K}$ = fator erodibilidade do solo: intensidade de erosão por unidade de índice de erosão da chuva, para um solo específico que é mantido continuamente sem cobertura, mas sofrendo as operações culturais normais, em um declive de $9 \%$ e comprimento de rampa de $25 \mathrm{~m}$, t/ha/ (MJ/ha.mm/ha);

$\mathrm{L}=$ fator comprimento do declive: relação de perdas de solo entre um comprimento de declive qualquer e um comprimento de rampa de $25 \mathrm{~m}$ para 0 mesmo solo e grau de declive; 
$S=$ fator grau de declive: relação de perdas de solo entre um declive qualquer e um declive de $9 \%$ para o mesmo solo e comprimento de rampa;

$\mathrm{C}=$ fator uso e manejo do solo: relação entre perdas de solo de um terreno cultivado em dadas condições e as perdas correspondentes de um terreno mantido continuamente descoberto, isto é, nas mesmas condições em que o fator $\mathrm{K}$ é avaliado.

$P=$ fator da prática conservacionista: relação entre as perdas de solo de um terreno cultivado com determinada prática e as perdas quando se planta morro abaixo.

As aplicações da EUPS são as mais variadas abrangendo desde estudos preditivos de erosão visando o manejo de práticas agrícolas em bacias hidrográficas, bem como instrumento de planejamento de áreas de proteção ambiental - APAs e de áreas urbanas e periurbanas (DONZELI et.al, 1992; PINTO, 1991 e 1996; FUJIHARA, 2002; VENIZIANI JUNIOR, 2003; PEDRO; LORANDI, 2004; COSTA, 2005; OLIVEIRA et al, 2007; GRILO; ENAMI, 2008).

Petsch et. all. (2012) ao elaborarem Cartas de Suscetibilidade e Potencialidade à Erosão Laminar para o município de Douradina/PR incluíram, dentre outras, a variável erodibilidade do solo com índices aplicados a partir da literatura. Os autores utilizaram ainda na equação de suscetibilidade e potencialidade o uso e ocupação do solo e a declividade, porém, salientam que para estudos erosivos mais afinados é recomendável a utilização de um maior número de variáveis.

Ruthes et. all. (2012), ao destacar as propriedades do solo da Bacia Hidrográfica do Rio Catorze/PR que intensificam a erosão laminar, buscaram o cruzamento de dados de campo - ao analisarem atributos físico-químicos do solo com a declividade para a determinação da erodibilidade do solo.

Neste artigo, o objetivo é verificar dois fatores desta equação, a Erosividade (Fator R) e a Erodibilidade (Fator K) para a área da Bacia Hidrográfica do Córrego João Dias, Aquidauana/MS, utilizando técnicas do geoprocessamento. 
A bacia do córrego João Dias localiza-se no município de Aquidauana/MS e possui área de 11.165,00 hectares (Figura 1). A bacia caracteriza-se pela diversidade de atividades produtivas, sendo que o seu alto curso é ocupado pela Aldeia indígena Limão Verde, onde a prática da agricultura é a principal atividade desenvolvida. O seu médio curso é ocupado por pequenas propriedades rurais na margem esquerda e grandes propriedades na margem direita, onde é desenvolvida a pecuária extensiva de corte e agricultura de subsistência. E o baixo curso compreende a área urbana do município de Aquidauana.

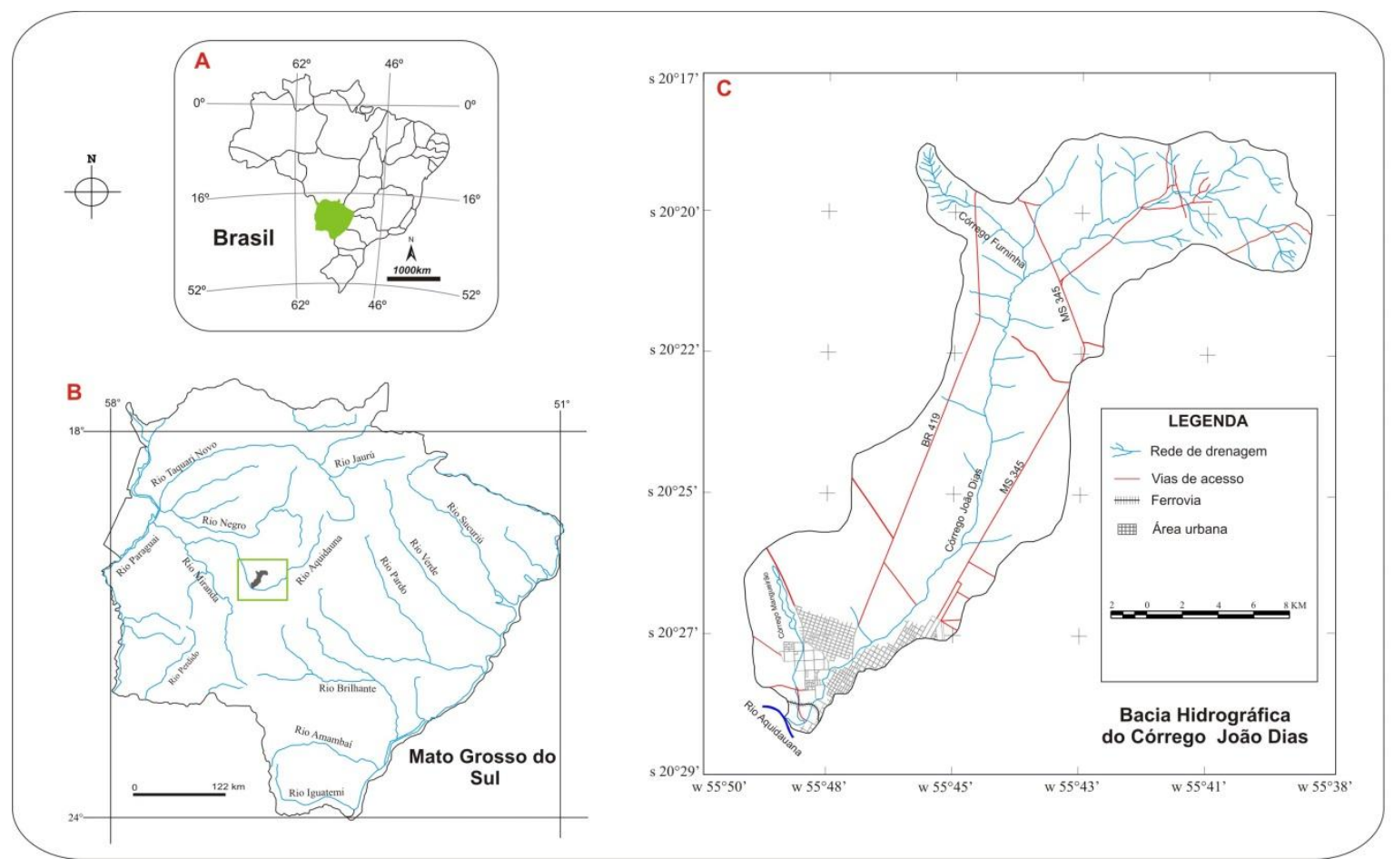

Figura 1 - Localização da área de estudo: (A) localização do Mato Grosso do Sul no Brasil; (B) localização da Bacia Hidrográfica do Córrego João Dias no Estado de Mato Grosso do Sul; (C) Bacia Hidrográfica do Córrego João Dias.

\section{MATERIAIS E MÉTODOS}

Para o desenvolvimento do trabalho foi montado um banco de dados utilizando-se do software Spring 5.2. A base de dados foi a Carta Topográfica do DSG (Departamento do Serviço Geográfico) de 1972, folha SF.21-X-A-III, na escala 1:100.000 e as fotografias aéreas da área provenientes do recobrimento aerofotogramétrico realizado de 1964 a 1966, da AST/USAF, na escala de 1: 60.000. 
As fotografias aéreas foram submetidas a procedimentos de equalização de seus níveis de cinza. Conforme salienta Rossetti (2007) os níveis de cinza contidos nas imagens aerofotogramétricas variam em função das características da área imageada, do momento do imageamento (geometria da cena) e do processo de geração das imagens (processamentos em laboratório fotográfico especializado).

Para a equalização das fotografias foi necessário realizar os cálculos dos parâmetros de ganho e offset, que consiste em igualar as médias e variâncias das imagens. Os valores da média e do desvio padrão foram obtidos a partir da função "análise estatística de amostras" e utilizada a seguinte fórmula:

Ganho $=(\mathrm{VR} / \mathrm{VE}) 1 / 2$

Offset $=$ MR $-($ ganho*ME), onde:

VR,VE,MR,ME são as variâncias e as médias das imagens de referência (R) e a ser equalizada $(E)$, respectivamente.

Após o cálculo do ganho e offset, executou-se a função de "operação aritmética" aplicando a seguinte fórmula:

$\mathrm{C}=$ ganho* $\mathrm{A}$ +offset, onde:

$A=$ imagem a ser modificada

$\mathrm{C}=$ imagem equalizada resultante

Para a determinação do Fator $\mathrm{R}$ - Erosividade foram instalados pluviômetros na bacia, bem como, solicitados dados de pluviômetros e estações já existentes, sendo as localizações espacializadas na Figura 2.

Para o cálculo da erosividade $(R)$ foi necessário determinar a média mensal do índice de erosão. Os dados desta média foram determinados através da Equação 2 elaborada por Lombardi Neto; Moldenhauer, citados por Bertoni e Lombardi Neto (2008), onde:

$$
\mathrm{El}=67,355\left(\mathrm{r}^{2} / \mathrm{P}\right)^{0,85} \quad \text { (Equação 2) }
$$

em que:

$\mathrm{El}=$ Média mensal do índice de erosão, $\mathrm{MJ} \mathrm{mm} \mathrm{ha}^{-1} \mathrm{~h}^{-1}$;

$r=$ precipitação média mensal, $\mathrm{mm}$; e

$\mathrm{p}=$ precipitação média anual, $\mathrm{mm}$. 


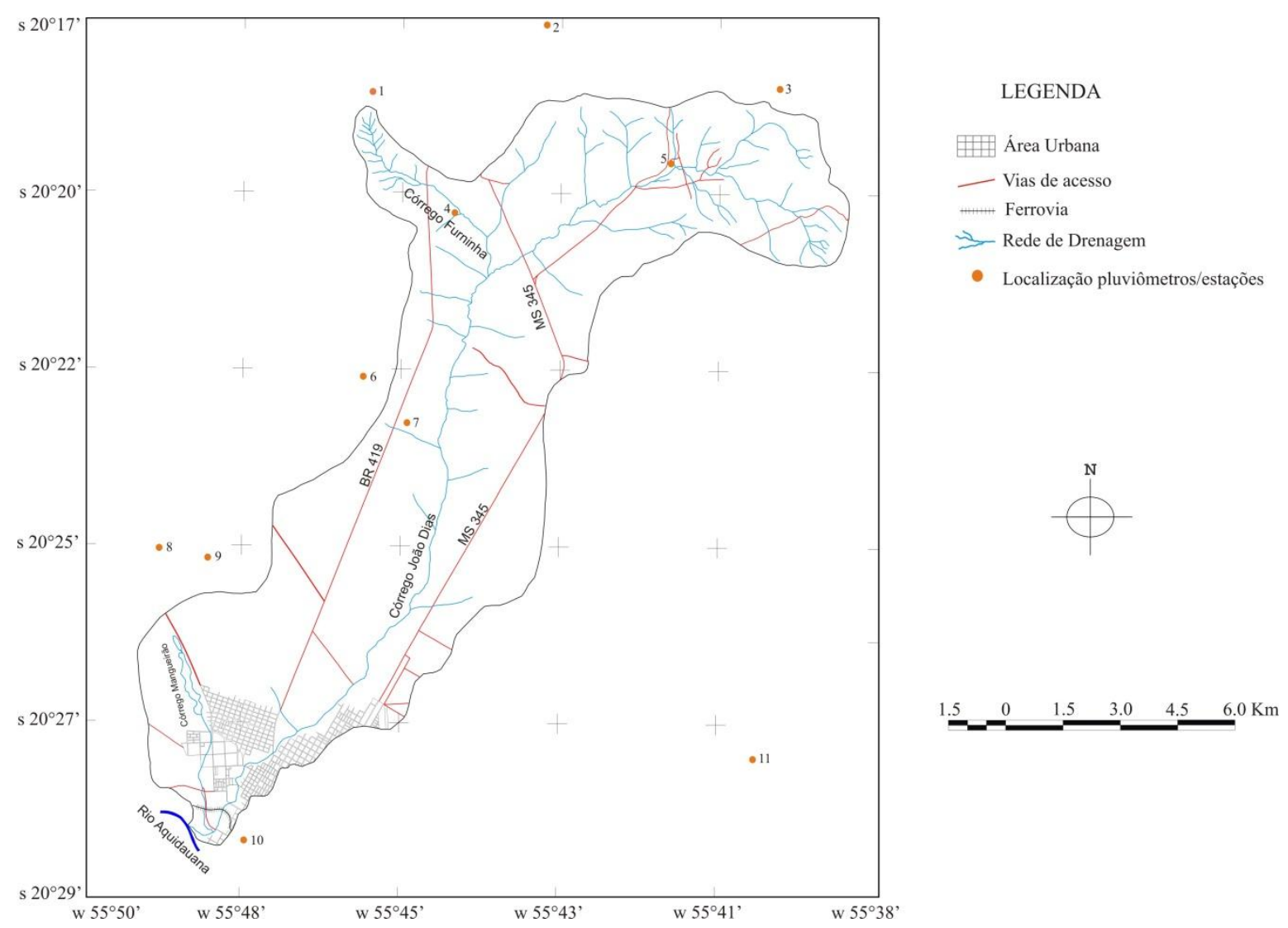

Figura 2. Localização dos pontos de coleta de dados dos pluviômetros/ estações na bacia hidrográfica do Córrego João Dias e entorno.

Os dados pluviométricos foram manipulados no software Excel, agrupados e somados para o cálculo das médias e aplicação da fórmula. Os valores de 'p' foram obtidos através do somatório dos 'r'. Por meio da Equação aplicando-se os valores de 'r' e 'p', calculou-se o El mensal da série das estações/pluviômetros. A soma dos valores mensais de El forneceu o valor da erosividade $(R)$.

Com os dados de erosividade $(\mathrm{R})$, utilizou-se o software Surfer $8.0 \AA$ para a interpolação destas informações. A tabela gerada no Excel com a localização dos pluviômetros ( $\mathrm{X}$ e $\mathrm{Y}$ ) e o valor de erosividade $(Z)$ foi importada no Surfer, gerando-se um arquivo da malha de amostragem com os dados dispostos regularmente, sendo utilizado o interpolador - inverso do quadrado da distância. A partir da malha foi gerado o mapa de contornos apresentando as curvas de isovalores (Figura 3). Após a edição o resultado foi exportado para o SPRING. 

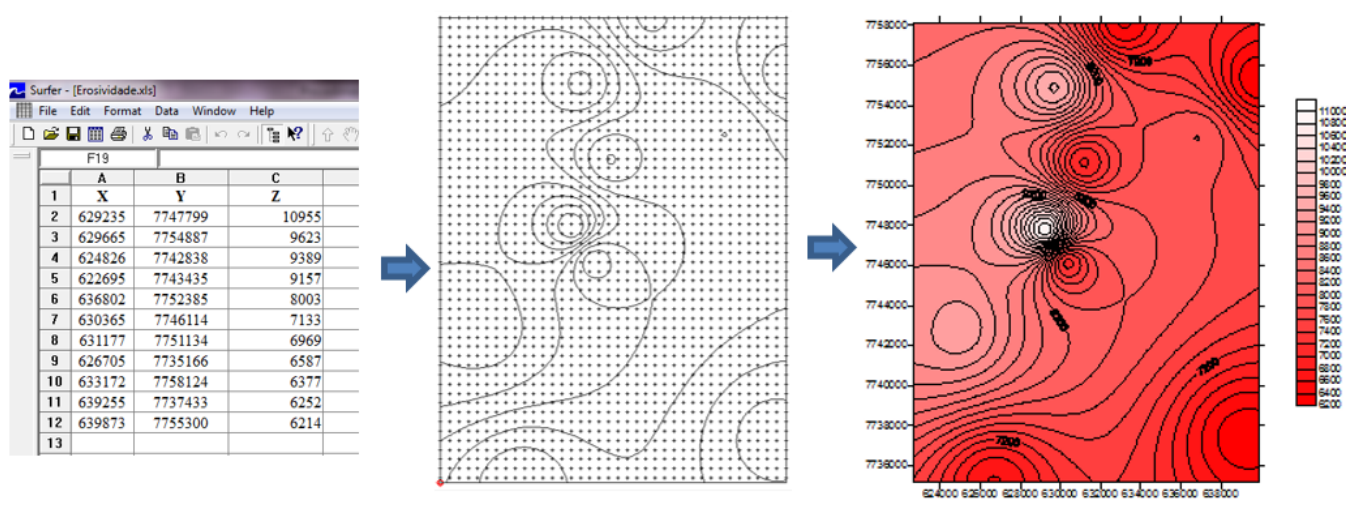

Figura 3 - Procedimentos para a interpolação dos dados de Erosividade no software Surfer 8.0.

Para a determinação do Fator K - Erodibilidade do solo refinou-se a escala, pois a escala do mapa de solos utilizado (compilado de PCBAP, 1997) era de 1:250.000. A proposta do trabalho não foi reclassificar os solos existentes na bacia e sim realizar análise da textura (fração menor que $2 \mathrm{~mm}$ de diâmetro) em amostras para melhor caracterização do potencial erosivo dos solos. Para tanto foram utilizadas técnicas de fotopedologia, considerando elementos como: o relevo, a rede de drenagem, a vegetação e o uso atual.

O primeiro procedimento foi a delimitação das quebras de relevo através das fotografias aéreas da área (1:60.000), considerando também os diferentes usos e cobertura da terra, bem como, declividade e densidade de drenagem.. Após a delimitação dessas áreas foram realizadas amostragens de campo com trado, em um total de 10 pontos (Figura 4). Em cada ponto foram coletadas amostras na profundidade de $0-30 \mathrm{~cm}$ (superficial) e $30-60 \mathrm{~cm}$ (subsuperficial) conforme Santos et.al. (2005).

Para melhor descrição do local da coleta, bem como, do material coletado foi elaborada uma planilha de campo, de acordo com IBGE (2007). A Figura 5 apresenta as etapas de coleta, bem como as áreas selecionadas.

Para a análise das amostras foi utilizado o método da Pipeta (EMBRAPA, 1997). A partir dos resultados foi determinada a relação textural entre os horizontes de superfície e subsuperfície, visando avaliar a infiltração e permeabilidade do solo. Para tanto foi utilizada a seguinte expressão:

\section{RT $=(\%$ Arg. B) / (\% Arg. A) (Equação 3)}

Onde:

RT é a relação textural da fração argila; 
(\% Arg. B) representa a distribuição média porcentual da argila no horizonte B;

(\% Arg. A) representa a distribuição média porcentual da argila no horizonte A.

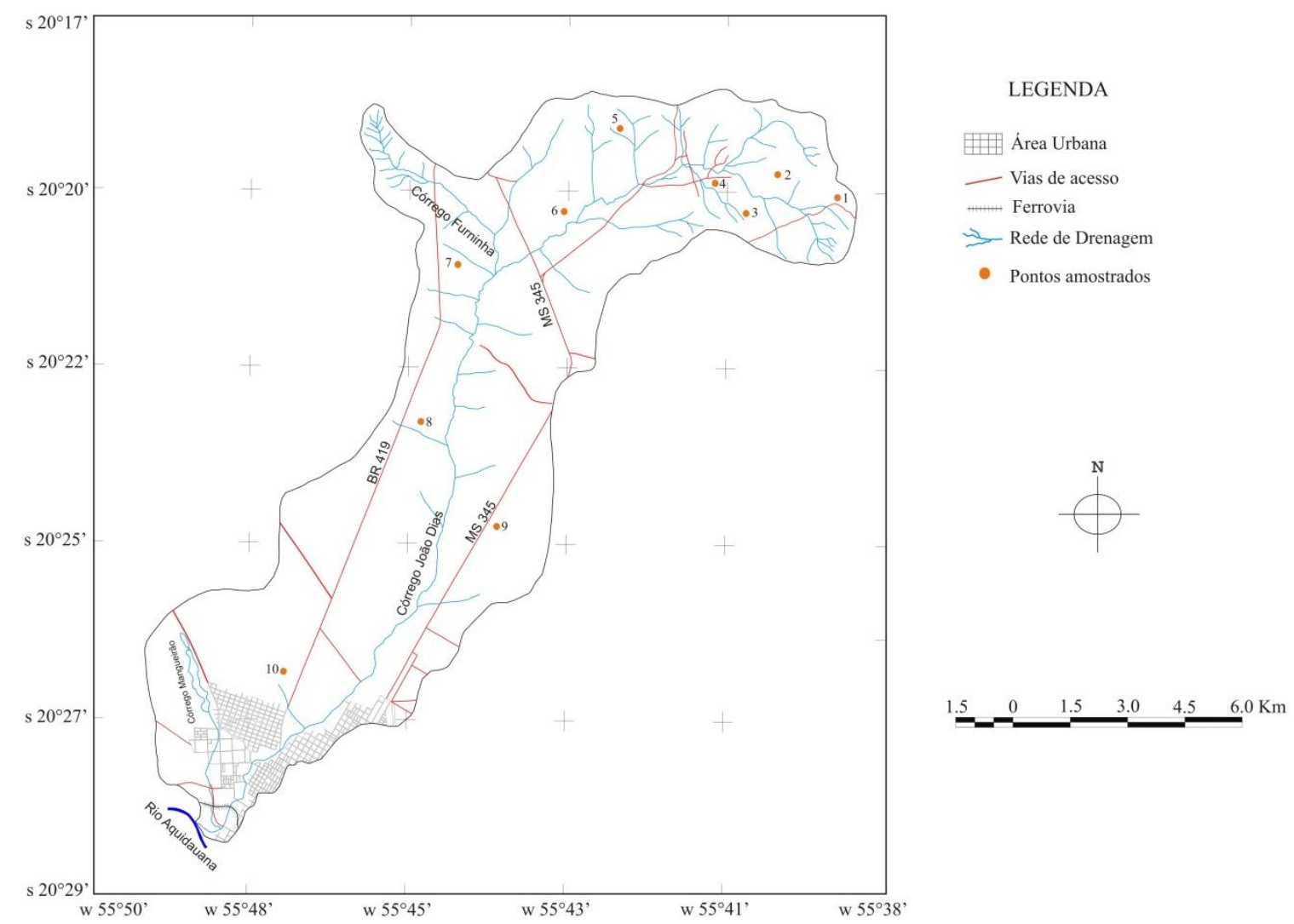

Figura 4 - Localização dos pontos onde foram coletadas amostras de solo na bacia hidrográfica do Córrego João Dias, Aquidauana/MS.

De acordo com Mannigel et.al. (2002, p. 1335)

\begin{abstract}
avaliações experimentais do valor do fator erodibilidade (K), conforme as normas estabelecidas pela equação universal de perda de solo, além de demandarem excessivos gastos também exigem muito tempo nas suas determinações, uma vez que trabalham com o processo direto da causa e efeito, que é o fenômeno da erosão do solo. Tais motivos tornaram necessária a estimativa do fator $\mathrm{K}$ por outros meios mais fáceis, denominados métodos indiretos de determinação da erodibilidade.
\end{abstract}

O referido autor cita exemplos de pesquisadores que determinaram o fator erodibilidade para solos brasileiros e norteamericanos, através da análise de alguns dos seus parâmetros físicos e químicos.

Nesse contexto, na presente proposta, o fator erodibilidade do solo (K) foi calculado pelo método indireto, para cada horizonte através da seguinte expressão de Bouyoucos (citado por Mannigel et.al., 2002): 
Fator $\mathrm{K}=((\%$ areia $+\%$ silte $) /(\%$ argila $)) / 100$ (Equação 4)

Onde: $\mathrm{K}$ = erodibilidade do solo de cada subhorizonte (t.ah.h./ ha.MJ.mm);

$\%$ areia, \% silte e \% argila = porcentagem das respectivas frações para cada horizonte.

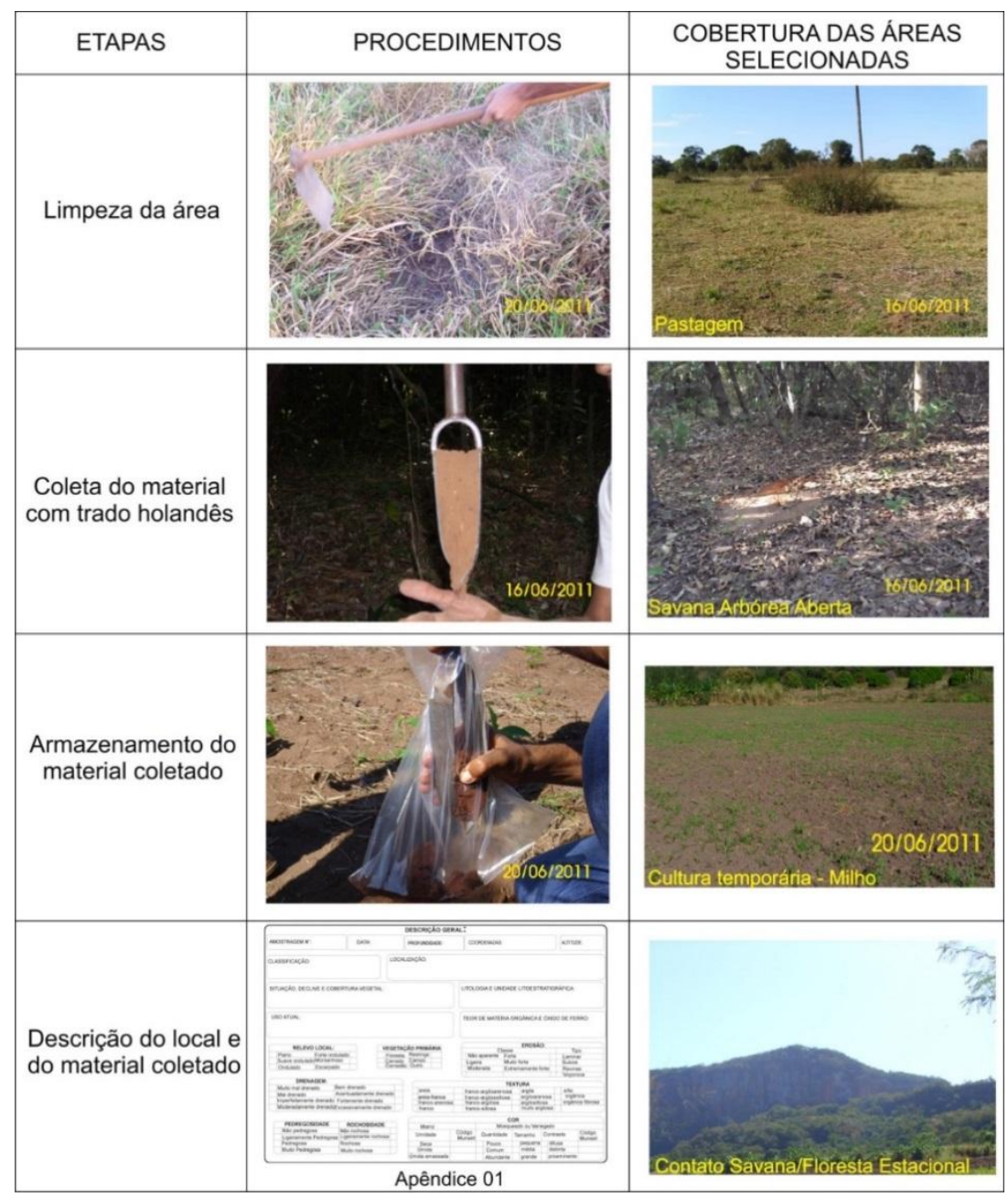

Figura 5 - Procedimentos metodológicos utilizados nas etapas da coleta de amostras de solos na bacia hidrográfica do Córrego João Dias, Aquidauana/MS.

Dessa forma foi calculado o fator $\mathrm{K}$ para cada horizonte (superficial, subsuperficial) através da média aritmética entre os valores dos horizontes. Após os cálculos foi utilizada a classificação proposta por Mannigel et.al. (2002) quanto às classes de erodibilidade, sendo:

a) Extremamente alto: para o fator $\mathrm{K}$ maior do que 0,0600 t.ah.h./ ha.MJ.mm;

b) Muito alto: para valores de $\mathrm{K}$ entre 0,0450 e 0,0600 t.ah.h./ ha.MJ.mm;

c) Alto: para valores de $\mathrm{K}$ entre 0,0300 e 0,0450 t.ah.h./ ha.MJ.mm;

d) Médio: para valores de K entre 0,0150 e 0,0300 t.ah.h./ ha.MJ.mm; 
e) Baixo: para valores de K entre 0,0090 e 0,0150 t.ah.h./ ha.MJ.mm;

f) Muito baixo: para valores de $\mathrm{K}$ menores do que 0,0090 t.ah.h./ ha.MJ.mm.

As informações foram espacializadas considerando a delimitação realizada através das fotografias aéreas, sendo que, as amostras também foram coletadas utilizando este critério.

As classes identificadas como nula no mapa de erosividade foram inseridas a partir do mapeamento geológico da área, sendo estas, correspondentes aos depósitos aluvionares.

\section{RESULTADOS E DISCUSSÕES}

De acordo com Bertoni; Lombardi Neto (2008) o fator de erosividade da chuva $(R)$ é um índice numérico que expressa à capacidade da chuva, esperada em dada localidade, de causar erosão em uma área sem proteção.

$\mathrm{Na}$ presente pesquisa os valores de Erosividade foram obtidos através da equação descrita por Lombardi Neto; Moldenhauer, citados por Bertoni e Lombardi Neto (2008), a partir de dados de 11 pluviômetros/estações localizados na bacia e em seu entorno. Os valores do fator $\mathrm{R}$ obtidos em cada ponto estão descritos na Tabela 1.

Tabela 1. Valores do fator $\mathrm{R}$ para os pontos de coleta localizados na bacia e em seu entorno.

\begin{tabular}{c|c|c}
\hline Ponto & Localização & Erosividade (MJ.mm/ha.h) \\
\hline $\mathbf{0 1}$ & $0626705 / 7735166$ & 6587 \\
\hline $\mathbf{0 2}$ & $0636802 / 7752385$ & 8003 \\
\hline $\mathbf{0 3}$ & $0629235 / 7747799$ & 10955 \\
\hline $\mathbf{0 4}$ & $0631177 / 7751134$ & 6969 \\
\hline $\mathbf{0 5}$ & $0630365 / 7746114$ & 7133 \\
\hline $\mathbf{0 6}$ & $0624826 / 7742838$ & 9389 \\
\hline $\mathbf{0 7}$ & $0622695 / 7743435$ & 9157 \\
\hline $\mathbf{0 8}$ & $0629665 / 7754887$ & 9623 \\
\hline $\mathbf{0 9}$ & $0633172 / 7758124$ & 6377 \\
\hline $\mathbf{1 0}$ & $0639873 / 7755300$ & 6214 \\
\hline $\mathbf{1 1}$ & $639255 / 7737433$ & 6252 \\
\hline
\end{tabular}


A partir da Tabela 1 verifica-se que os valores de $R$ variaram de 6214 a 10955 MJ.mm/ha.h. Na Figura 6, observa- se que a erosividade na bacia do Córrego João Dias tem valores mínimos entre 6200 a 7000 MJ.mm/ha.h na foz do Córrego e também na porção nordeste, em seu alto curso. Os valores de erosividade aumentam em direção ao oeste da bacia, onde os valores chegam a 9400 a 10200 MJ.mm/ha.h.

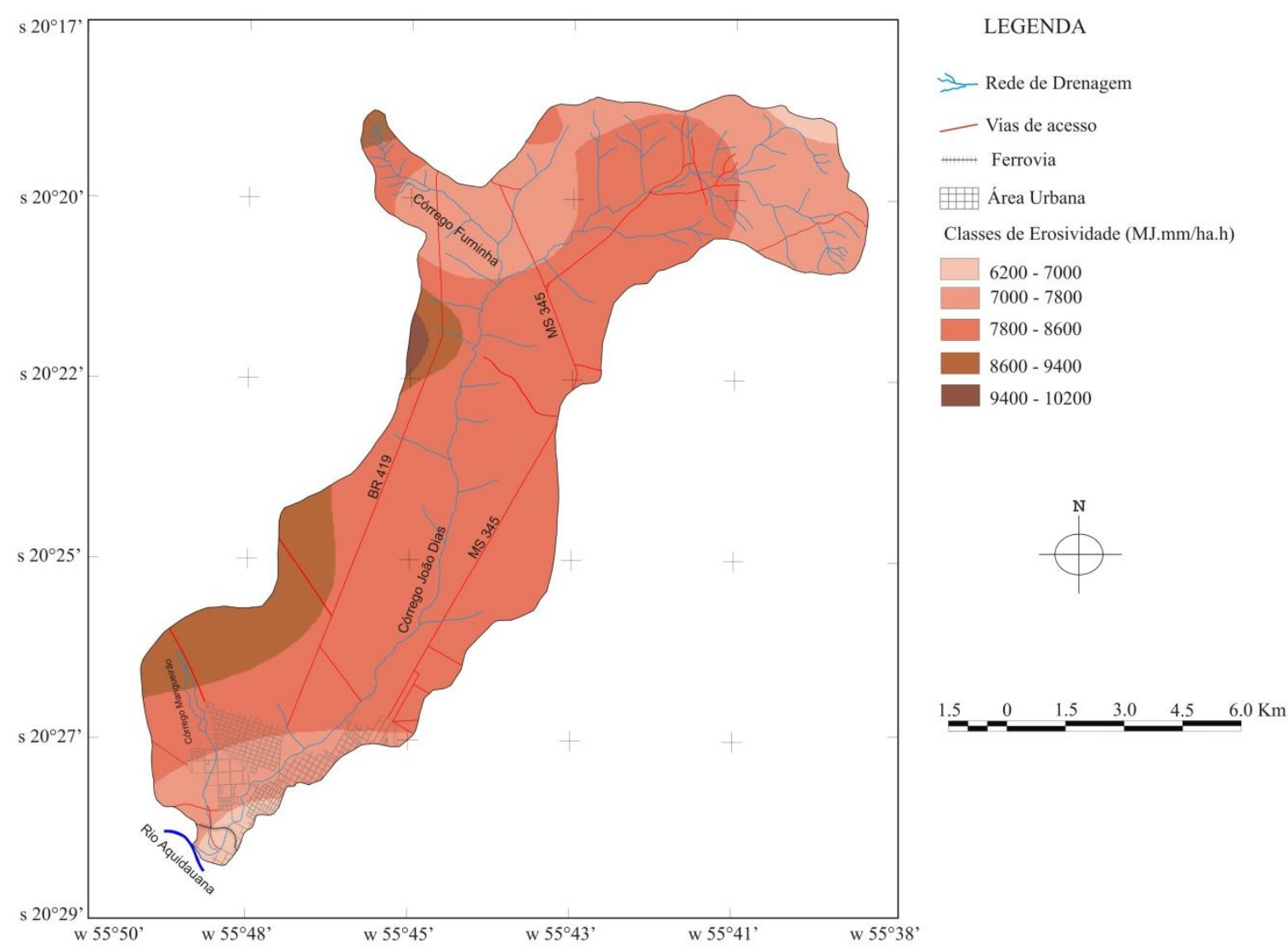

Figura 6 - Mapa de distribuição de classes de Erosividade da bacia hidrográfica do Córrego João Dias, Aquidauana/MS.

Predomina na bacia a classe de erosividade que varia de 7800 a 8600 MJ.mm/ha.h, ocupando área de 7.253 ha, o equivalente a $62 \%$ da área da bacia. Essa classe se estende na direção sudoeste-nordeste em áreas do baixo, médio e alto curso da bacia.

A Erodibilidade é a capacidade de um solo ser mais facilmente erodido do que outros, mesmo quando fatores como declividade, precipitação, cobertura vegetal e as práticas e controle de erosão forem os mesmos. Isso se deve a diferença das propriedades inerentes ao solo como permeabilidade, estrutura, densidade e textura. 
Para avaliar a erodiblidade dos solos na bacia considerou-se a textura e a permeabilidade dos solos através da análise da relação textural. A Figura 7 demonstra a espacialização das classes de erodibilidade encontradas na bacia, sendo que, a classe de erodibilidade considerada como Extremamente Alta localizase principalmente no alto curso, em área de nascentes, ocupa área de 793,01 ha, correspondendo a 6,79\% da área da bacia (Tabela 2).

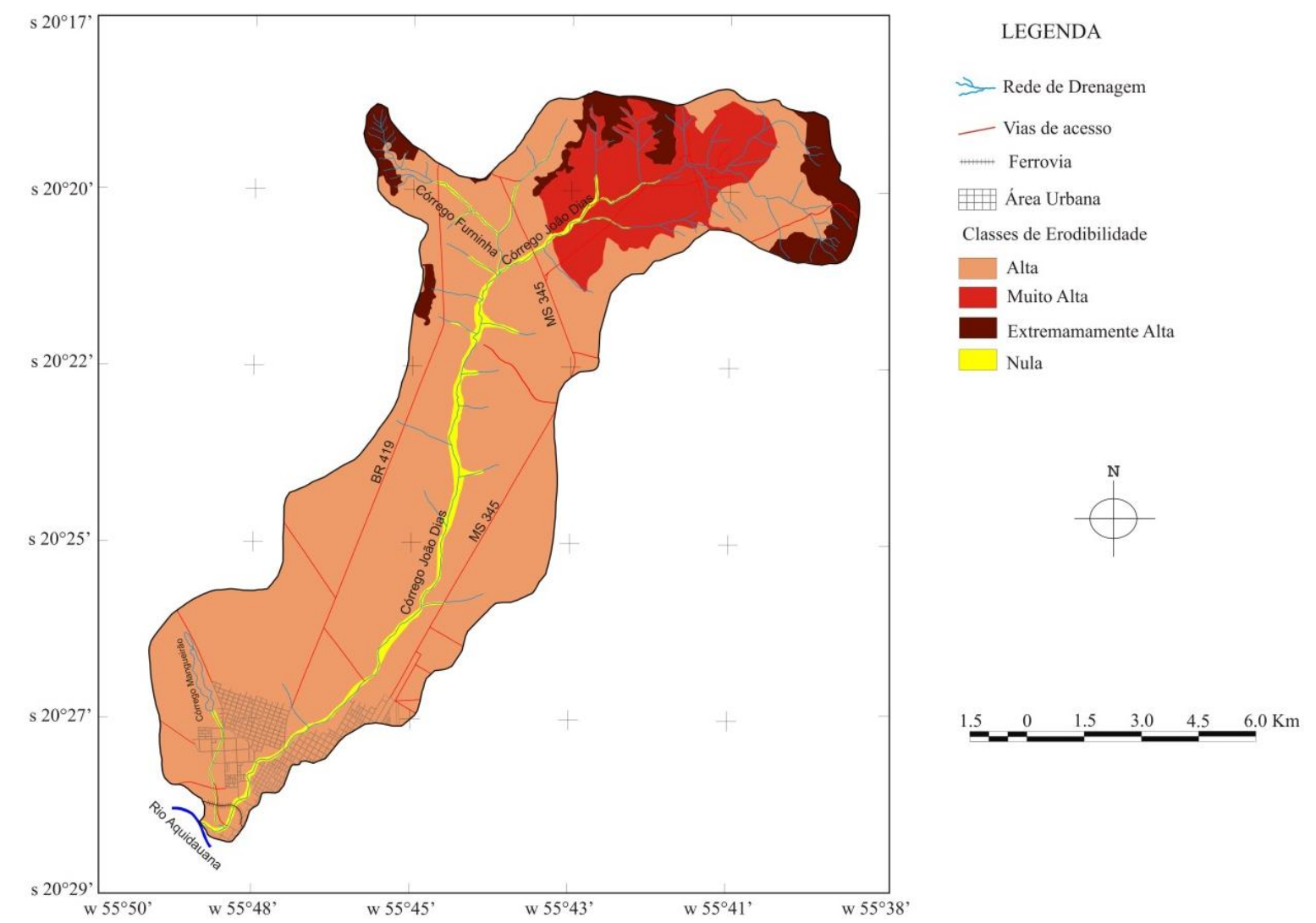

Figura 7 - Mapa de distribuição de classes de Erodibilidade da bacia hidrográfica do Córrego João Dias, Aquidauana/MS.

Tabela 2. Classes de Erodibilidade e suas respectivas áreas na bacia hidrográfica do Córrego João Dias, Aquidauana/MS.

\begin{tabular}{l|c|c|c}
\hline \multicolumn{1}{c|}{ Classes } & K (t.ah.h./ ha.MJ.mm) & Área (ha) & Área (\%) \\
\hline Extremamente Alta & 0,0785 & 793,01 & 6,79 \\
\hline Muito Alta & 0,0545 & $1.407,33$ & 12,06 \\
\hline Alta & 0,0397 & $9.102,48$ & 78,03 \\
\hline Nula & 0 & 362,80 & 3,12 \\
\hline
\end{tabular}


Quanto à relação textural, as amostras apresentaram teor de argila relativamente uniforme entre os horizontes de superfície e subsuperfície, drenagem variando de acentuada a imperfeita e textura franco-arenosa.

O mapa de solos (Figura 8) demonstra que essas áreas (erodibilidade Extremamente Alta) são caracterizadas por neossolos. Segundo a descrição da Embrapa (1999) estes compreendem solos constituídos por material mineral, ou por material orgânico pouco espesso, que não apresentam alterações expressivas em relação ao material originário devido à baixa intensidade de atuação dos processos pedogenéticos.

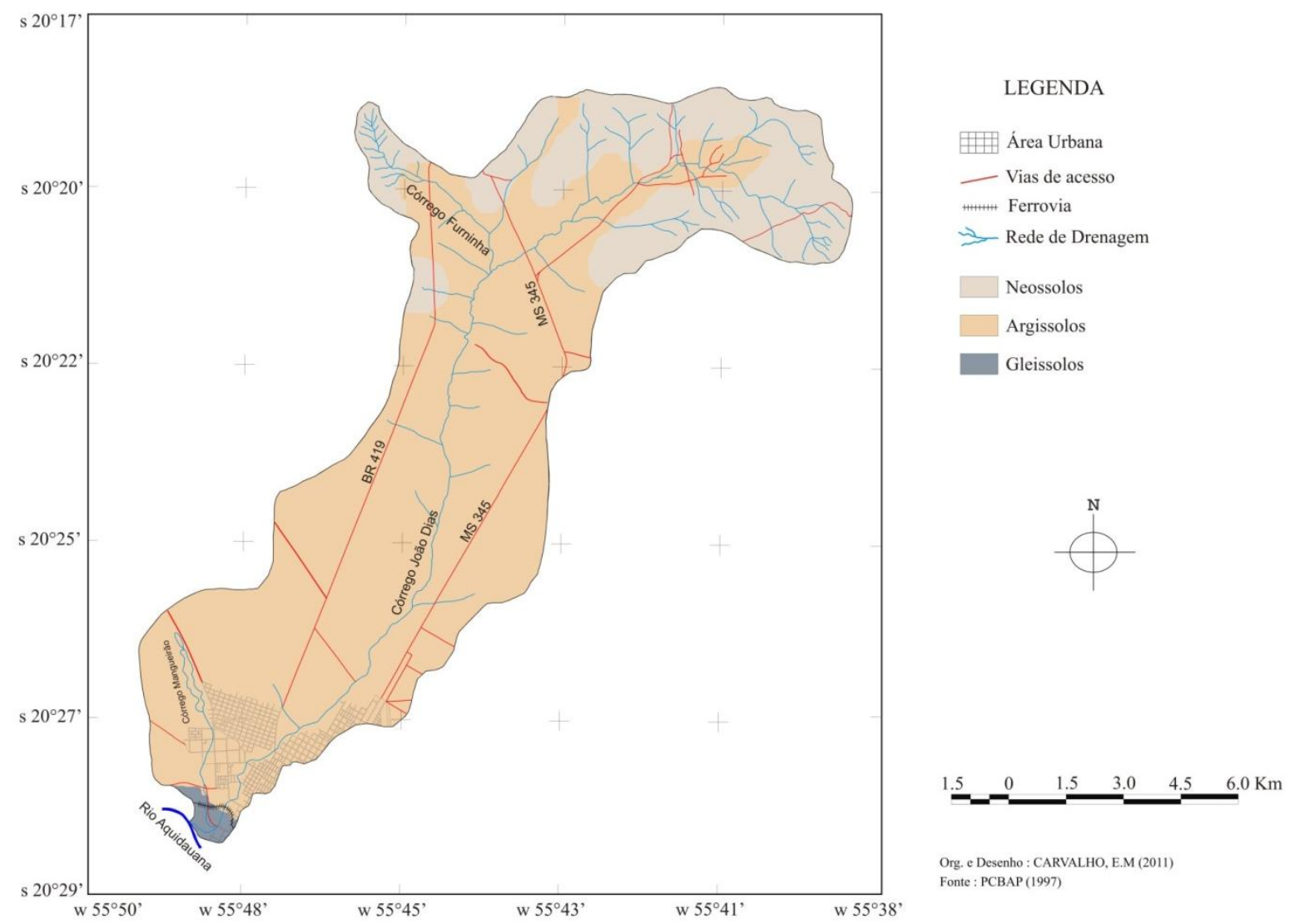

Figura 8 - Mapa de solos da bacia hidrográfica do Córrego João Dias, Aquidauana/MS.

Guerra e Botelho (2003) salientam que devido à pequena espessura desses solos, o fluxo d'água em seu interior é precocemente interrompido, facilitando o escoamento em superfície, gerado pela rápida saturação do solo, e em subsuperfície, na zona de contato solo-rocha. Tal situação pode responder pela ocorrência de processos erosivos e, mais especificamente, de deslizamentos, se agravando nas encostas mais íngremes e desprovidas de vegetação. 
É justamente nessas áreas (erodibilidade Extremamente Alta) que localizamse as áreas mais íngremes da bacia, com declives que variam entre 12 a > que $20 \%$, conforme demonstrado pela Figura 9.

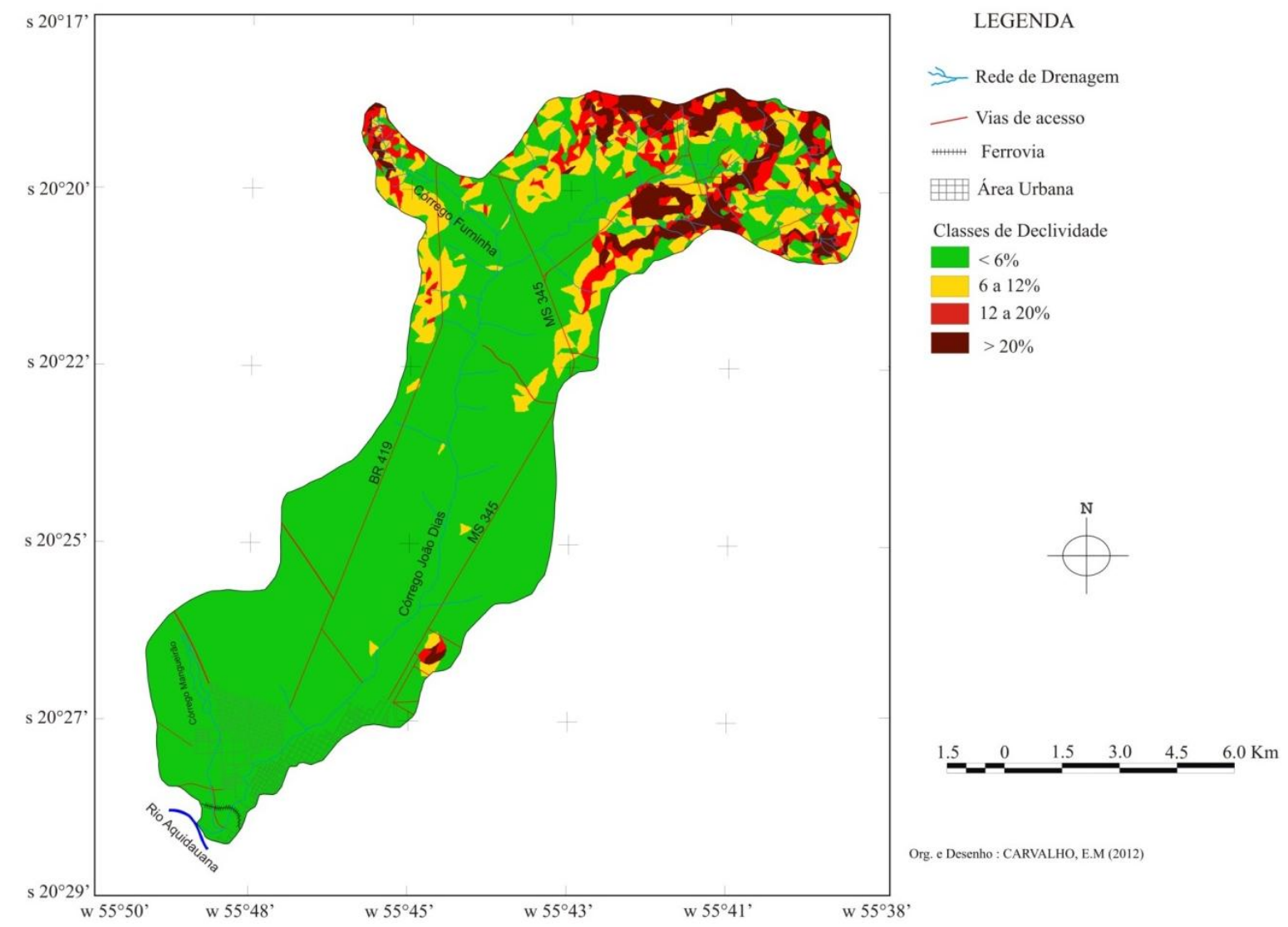

Figura 9 - Mapa de distribuição das classes de Declividade da bacia hidrográfica do Córrego João Dias, Aquidauana/MS.

Ao analisar a Figura 10, observa-se que praticamente toda essa área é recoberta por vegetação natural, contribuindo assim, para a contenção de processos erosivos. Também constata-se a nítida relação entre as áreas mais íngremes e a presença de vegetação natural na bacia, demonstrando a dificuldade de ocupação pela pecuária de tais áreas.

Ao analisar os mapas de erosividade e erodibilidade observa-se que a classe de erodibilidade Extremamente Alta na porção oeste e noroeste da bacia, no alto curso, coincidem com áreas onde o índice de erosividade são maiores (9400 a 10200/ 8600 a 9400 MJ.mm/ha.h) apontando estas áreas como mais suscetíveis à erosão laminar. 


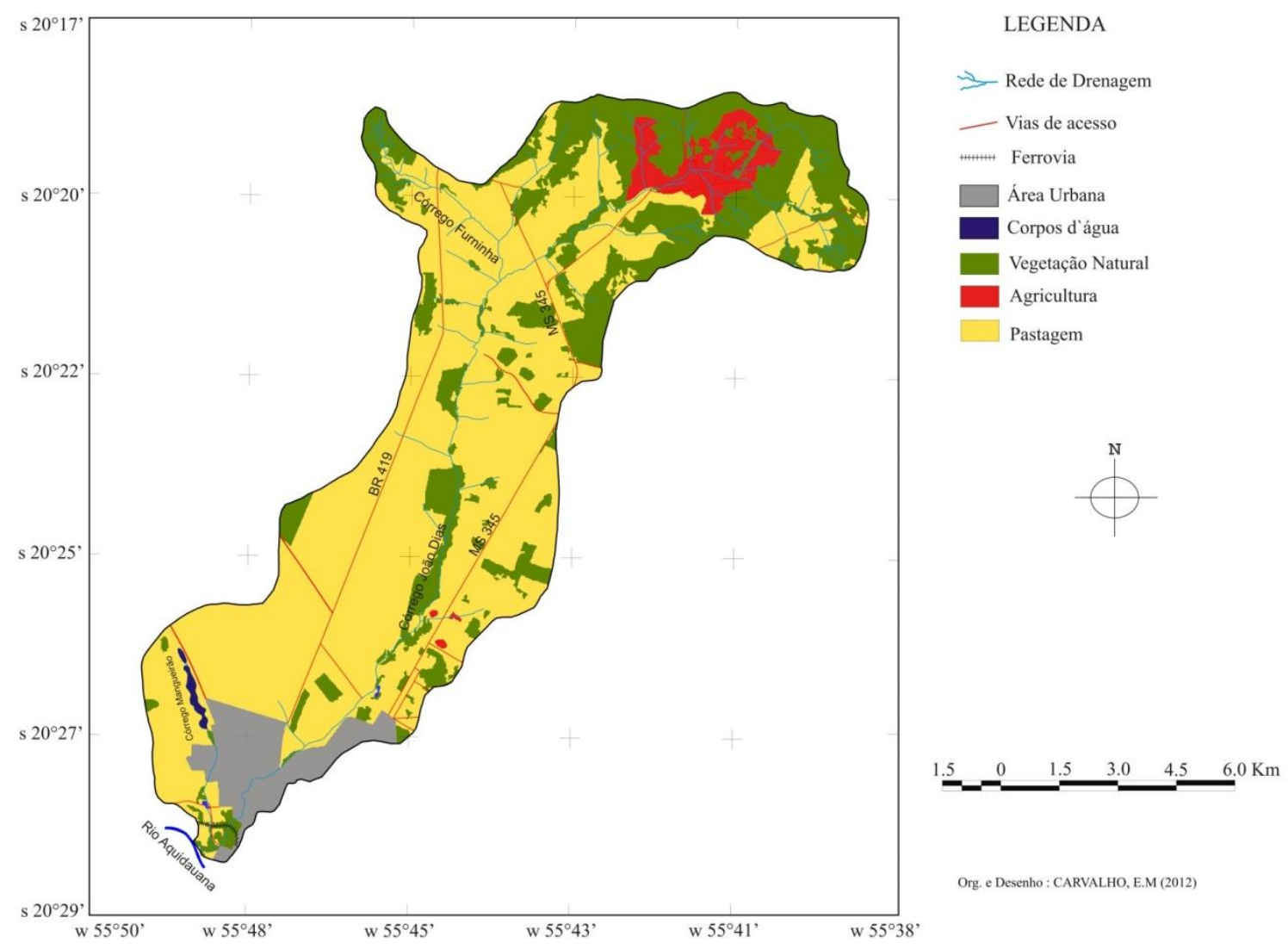

Figura 10 - Mapa de uso da terra da bacia hidrográfica do Córrego João Dias, Aquidauana/MS

Tais fatores associados ao tipo de solo, à declividade do terreno, uso, ocupação e manejo da terra podem contribuir para maior perda de solo. A Figura 11 demonstra tal situação ao retratar área com classe de erodibilidade Extremamente Alta, na porção noroeste da bacia, sendo utilizada para a pecuária extensiva e sem a utilização de práticas conservacionistas, em áreas com declives entre 12 a 20\%, propiciando com as precipitações maior probabilidade de perda de solo.

Cerca de $64,45 \%$ da área da bacia é ocupada por pastagens, sendo que, em alguns locais a mesma se estende até as margens do Córrego João Dias (Figura 10). Quanto às práticas conservacionistas, 76,20\% das propriedades amostradas não utilizam nenhuma técnica, e 23,80\% utilizam técnicas como a curva-de-nível e a correção do solo com calcário.

$\mathrm{Na}$ bacia a utilização de práticas conservacionistas está associada principalmente ao tamanho das propriedades, pois as pequenas propriedades rurais não possuem recursos para investimentos, enquanto que, as propriedades maiores utilizam práticas para aumentar a produção. 


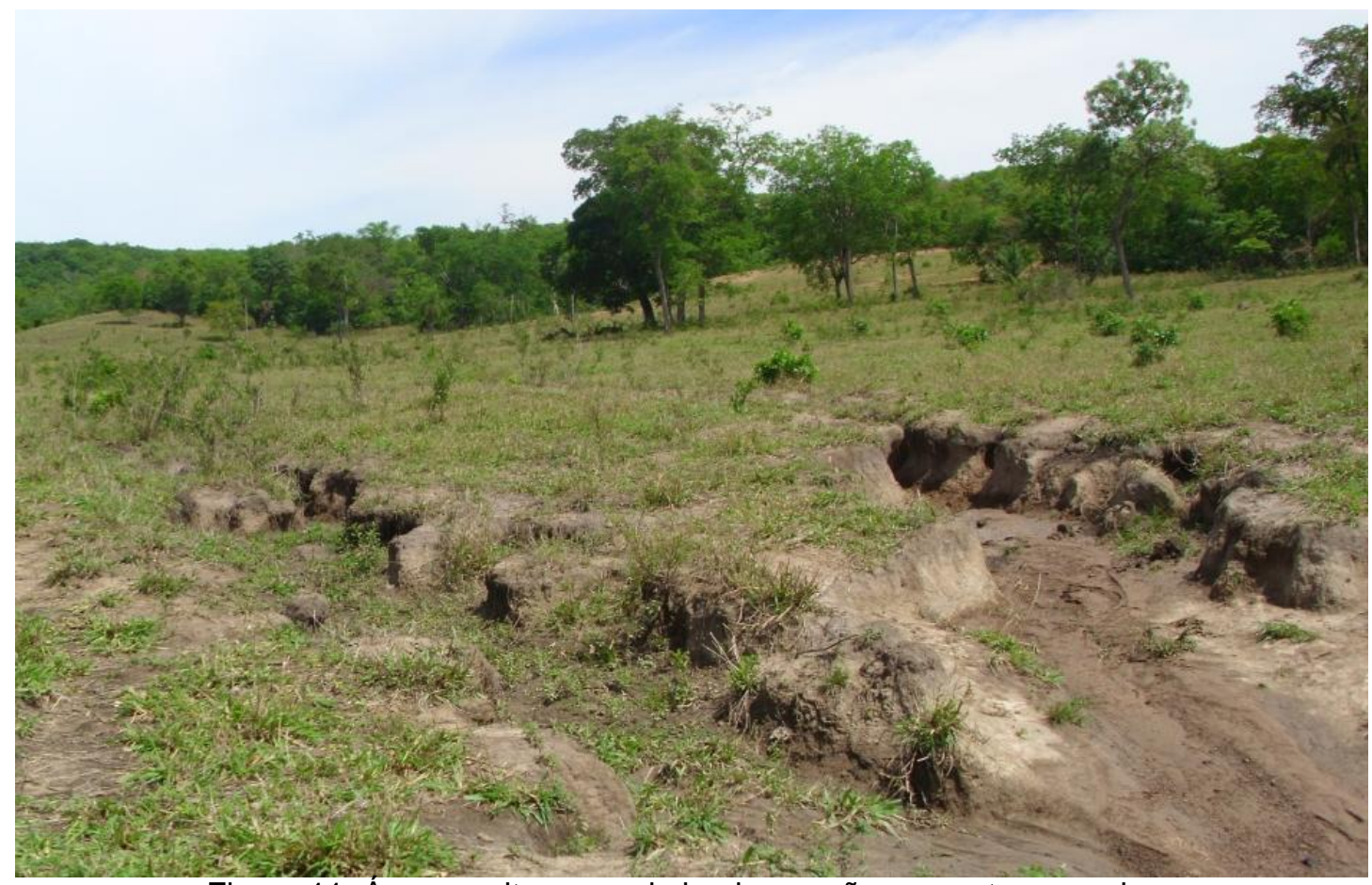

Figura 11. Area no alto curso da bacia, porção noroeste, com classe de erodibilidade extremamente alta.

A classe de erodibilidade Muito Alta compreende cerca de 12,06\% da área da bacia e localiza-se também no alto curso, na porção nordeste (Figura 7). As amostras demonstraram textura Franco-Arenosa no horizonte A e Franco-ArgiloArenosa no horizonte $B$, apresentando incremento de argila no horizonte $B$, caracterizando uma relação textural alta de argila.

Segundo Mannigel et.al (2002) a relação textural de argila, entre os horizontes de subsuperfície e superfície, afeta principalmente a infiltração e a permeabilidade do solo. Uma relação textural alta de argila indica capacidade de infiltração menor nos horizontes de subsuperfície, acelerando com isso, a intensidade de erosão dos horizontes superficiais.

De acordo com o mapa de solos (Figura 8) essa área é caracterizada por neossolos e argissolos, sendo este último, segundo a Embrapa (1999) constituídos por material mineral, que têm como características diferenciais a presença de horizonte $\mathrm{B}$ textural de argila de atividade baixa, ou alta conjugada com saturação por bases baixa ou caráter alítico. São de profundidade variável, desde forte a imperfeitamente drenados, de cores avermelhadas ou amareladas, e mais raramente, brunadas ou acizentadas. 
Essas áreas (erodibilidade Muito Alta) correspondem quase que totalmente as áreas ocupadas pela Terra Indígena Limão Verde, onde a prática da agricultura é a principal atividade desenvolvida (Figura 10). Os declives nessas áreas variam desde $<6 \%$ a $>$ que $20 \%$ (Figura 9 ).

A erosividade e a erodibilidade dessa área, atrelado ao fato da área desenvolver a prática da agricultura acentua a probabilidade de perda do solo, principalmente no período em que o mesmo está exposto (Figura 12), e considerando a relação textural alta de argila, o que favorece o escoamento superficial pela capacidade de infiltração menor no horizonte B.

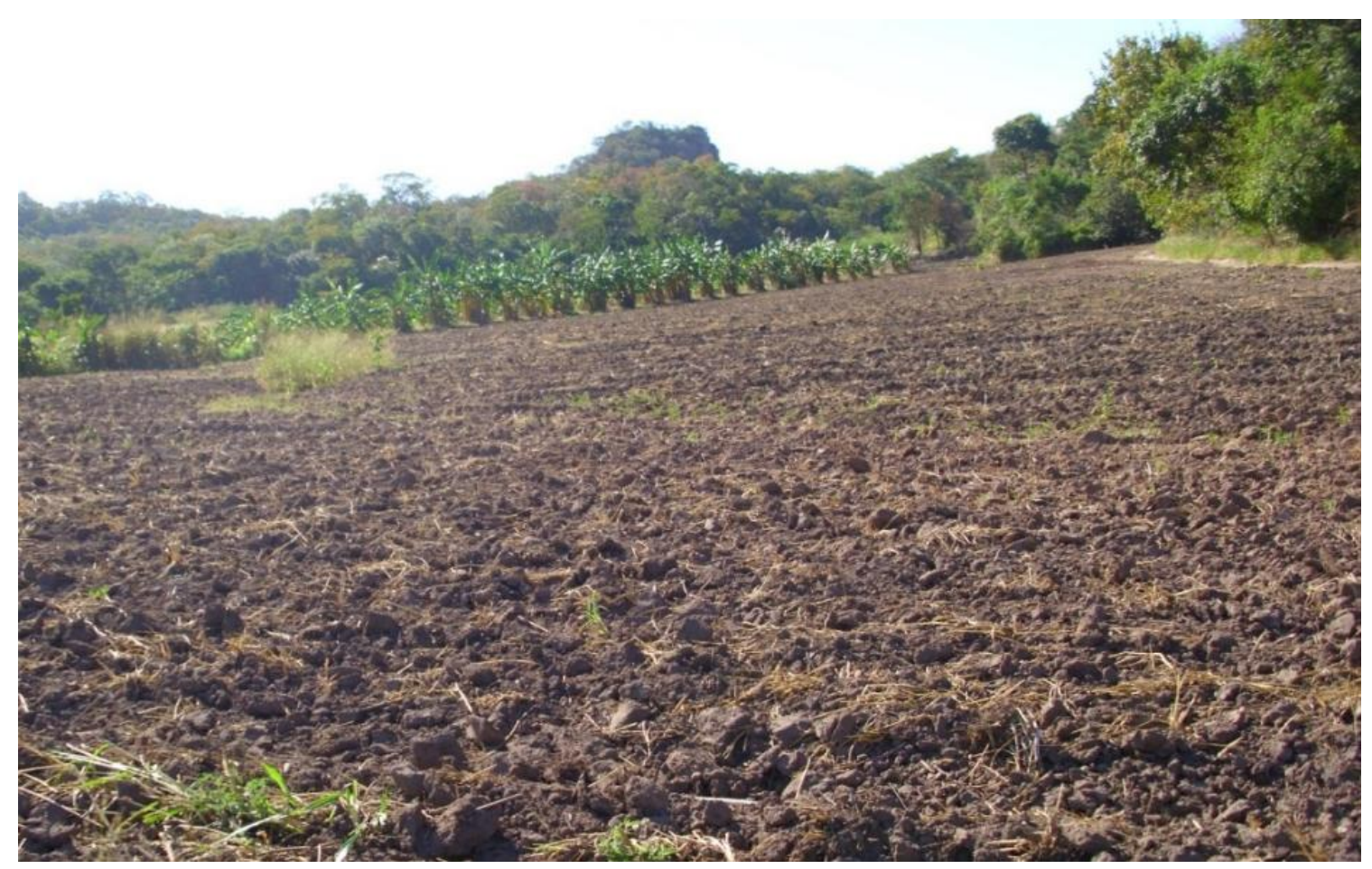

Figura 12. Solo exposto, sendo preparado para o plantio na Aldeia Limão Verde, Aquidauana/MS.

Cerca de $78,03 \%$ da bacia apresenta a classe de erodiblidade Alta, sendo as amostras caracterizadas por textura franco-arenosa, o incremento de argila do horizonte A para o B é pouco expressivo e variam de fortemente a bem drenados. Essas áreas são caracterizadas por gleissolos e argissolos (Figura 8).

Nessas áreas as classes de erosividade variam entre valores mínimos de 6200 a 7000 MJ.mm/ha.h na foz do Córrego e também na porção nordeste, em seu alto curso. Os valores de erosividade aumentam em direção ao oeste da bacia, onde os valores chegam a 9400 a 10200 MJ.mm/ha.h (Figura 06). Quanto à declividade 
essas áreas caracterizam-se principalmente por apresentarem declives menores que 6\% (Figura 09).

Mesmo apresentando declives baixos, a utilização dessas áreas para a prática da pecuária extensiva, sem utilização de práticas conservacionistas, pode influenciar na perda de solo, pois mesmo o solo não permanecendo descoberto em áreas de pastagens, favorecendo a infiltração, o pisoteio do gado promove a compactação do solo e cria caminhos preferenciais para o escoamento superficial, aumentando o risco de erosão. Esses caminhos são criados principalmente em direção aos córregos, pois os animais utilizam-se dessas águas para dessedentação (Figura 13).

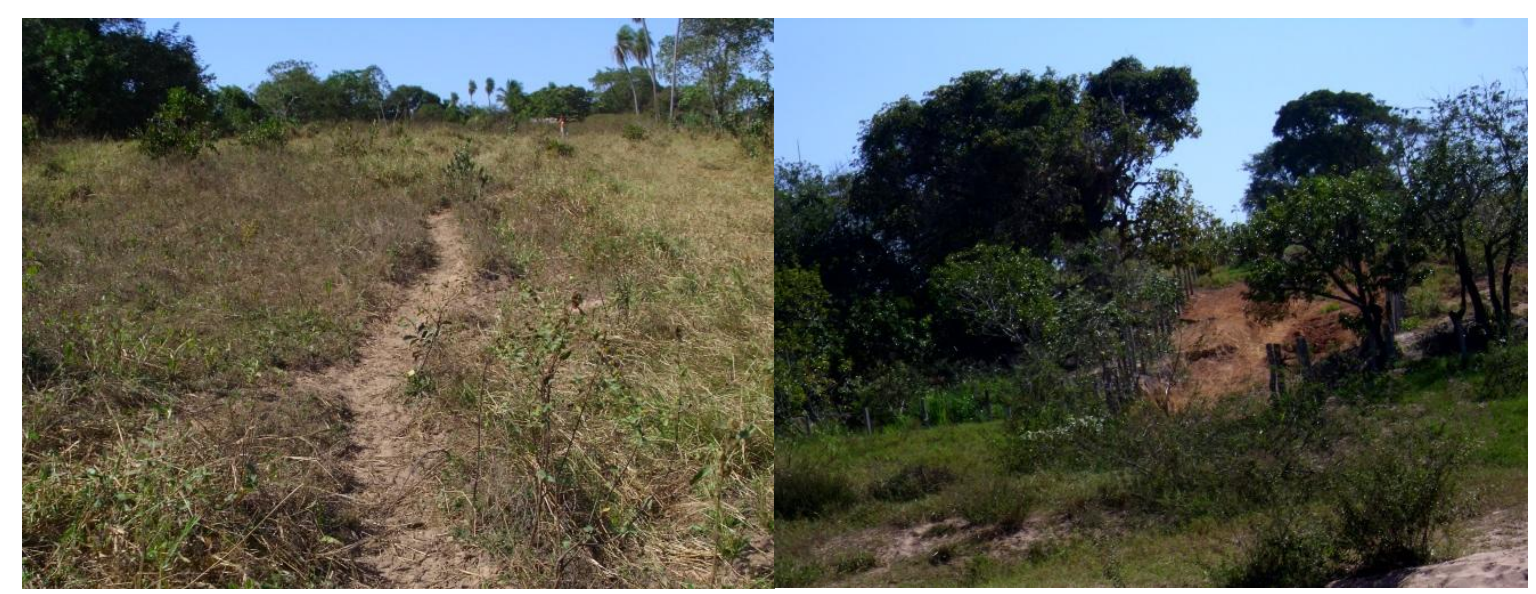

Figura 13. Caminhos preferenciais criados pelo pisoteio do gado no médio curso da bacia hidrográfica do Córrego João Dias.

Assim, para melhor utilização destas áreas, consideradas como de Erodibilidade Alta, torna-se necessária à utilização de práticas conservacionistas, mesmo sendo áreas com declives suaves e não necessitando de técnicas mais complexas de conservação, buscando evitar o surgimento de ravinas e perda de solos, e o comprometimento da qualidade das águas da bacia.

Nas margens do Córrego João Dias, localizam-se os depósitos aluvionares, sendo estes, nulos em relação ao fator $\mathrm{K}$ pelo fato de ser área de deposição.

\section{CONCLUSÃO}

$\mathrm{Na}$ constante busca de promover o desenvolvimento, as sociedades humanas, rurais ou urbanas, geram crescente gama de impactos ambientais. O mau 
uso, ocupação, gestão e controle da terra provocam inúmeros processos, que refletem no comprometimento dos recursos naturais, dentre eles, o solo e a água.

Ao identificarmos, no contexto espacial da Bacia Hidrográfica do Córrego João Dias, a erosividade e a erodibilidade do solo, tomamos conhecimento de áreas mais susceptíveis à erosão devido à distribuição e intensidade das chuvas, bem como, considerando a menor ou maior resistência das partículas do solo à desagregação e capacidade de absorver e infiltrar água pluvial.

$\mathrm{Na}$ bacia, áreas identificadas como de erodibilidade extremamente alta e muito alta apresentam o desenvolvimento de processos erosivos, principalmente ravinas, mesmo em áreas com erosividade baixa. Tal situação ocorre devido a fatores que exercem forte influência no desenvolvimento de processos erosivos, como a declividade dos terrenos e as formas de uso. Da mesma forma observa-se que áreas de alta erosividade e erodibilidade, mas com vegetação natural preservada, apresentaram maior resistência aos processos erosivos.

Nesse sentido a caracterização da erosividade (Fator $R$ ) e da erodibilidade (Fator K) possibilita não apenas a espacialização das informações, mas a obtenção de dados mais complexos no cruzamento com demais informações como uso, ocupação e manejo da terra, contribuindo assim, com o planejamento de bacias hidrográficas, gerando sugestões de práticas conservacionistas e de manejos mais indicados para os diferentes cenários.

\section{Referências}

BERTONI, J.; LOMBARDI NETO, F. Conservação do Solo. São Paulo: Ícone, 2008. 6a edição.

BIGARELLA, J. J. Estrutura e origem das paisagens tropicais e subtropicais. Florianópolis: UFSC, 2007. 2ª edição.

BRASIL. PCBAP - Plano de Conservação da Bacia do Alto Paraguai (Pantanal). Ministério do Meio Ambiente, dos Recursos Hídricos e da Amazônia Legal. Brasília, 1997.

BRASIL. Instituto Brasileiro de Geografia e estatística. Manual técnico de pedologia. $2^{\circ}$ edição. Rio de Janeiro, 2007. 
COSTA, A.L.C. Estudo da vulnerabilidade à erosão com a aplicação da Equação Universal de Perda de Solo na Alta Bacia Hidrográfica do Rio Jacaré Pepira, utilizando SIG/SPRING. 2005. 168 f. Dissertação (Mestrado em Geociências e meio ambiente). Instituto de Geociências e Ciências Exatas Universidade Estadual Paulista. Rio Claro, 2005.

DONZELI, P.; Valério Filho, M.; Pinto, S.A.F.; Nogueira, F.P.; Rotta, C.L.; Lombardi Neto. F. Técnicas de Sensoriamento Remoto Aplicado ao Diagnóstico Básico para o Planejamento e Monitoramento de Micro Bacias Hidrográficas. Campinas: Documentos IAC, $\mathrm{n}^{\circ}$ 29, 1992. p. 91-119.

EMBRAPA. Serviço Nacional de Levantamento e Conservação de solos. Manual de métodos de análise de solo. Rio de Janeiro: 1997. 212 p.

EMBRAPA. Centro Nacional de Pesquisa de Solos. Sistema Brasileiro de Classificação de Solos. Brasília: EMBRAPA, 1999.182 p.

FUJIHARA, A. K. Predição de Erosão e Capacidade de uso do solo numa microbacia do oeste paulista com suporte de geoprocessamento. 2002. $136 f$. Dissertação (Mestrado em Ciências). Escola Superior de Agricultura "Luiz de Queiroz"/USP. Piracicaba, 2002.

GRILO, R.C.; ENAMI, L. Gestão de bacias hidrográficas com o uso de modelo preditivo de erosão dos solos e sistemas de informação geográfica. UNAR. Araras/ SP, v.2, n.1, p. 21-33. 2008.

GUERRA, A.J. T.; MENDONÇA, J.K.S. Erosão dos solos e a questão ambiental. In: VITTE, A.C.; GUERRA, A.J.T. (orgs.). Reflexões sobre a geografia física no Brasil. Rio de Janeiro: Bertrand Brasil, 2004. p. 225 - 256.

GUERRA, A.J.T. Processos erosivos nas encostas. In: GUERRA, A. J. T.; CUNHA, S. B. da (Orgs.). Geomorfologia: uma atualização de bases e conceitos. Rio de Janeiro: Bertrand Brasil, 1995. p. 149 - 209.

GUERRA, A.J.T. O início do processo erosivo. In: GUERRA, A.J.T.;SILVA, A.S. BOTELHO, R.G.M. (orgs.) Erosão e Conservação dos Solos: conceitos, temas e aplicações. $2^{\mathfrak{a}}$ ed. Rio de Janeiro: Bertrand Brasil, 2005. p. 17-55.

GUERRA, A.J.T.; BOTELHO, R.G.M. Erosão dos Solos. In: Geomorfologia do Brasil. Rio de Janeiro: Bertrand Brasil (2003). P. 181-227.

LEPSCH, I. F. Formação e conservação dos solos. São Paulo: Oficina de textos, 2002.

MAFRA, N. M. C. Erosão e Planificação de uso do solo. In: GUERRA, A.J.T.; SILVA, A.S. BOTELHO, R.G.M. (orgs.). Erosão e Conservação dos Solos: conceitos, temas e aplicações. $2^{a}$ ed. Rio de Janeiro: Bertrand Brasil, 2005. p. 301- 322. 
MANNIGEL, A.R.; CARVALHO,M.P.; MORETI, D.; MEDEIROS,L.R. Fator Erodibilidade e tolerância de perda dos solos do Estado de São Paulo. Acta Scientiarum. Maringá, v.24.n.5, p. 1335-1340. 2002.

OLIVEIRA, A.M.M.; PINTO, S.A.F; LOMBARDI NETO, F. Caracterização de indicadores da erosão do solo em bacias hidrográficas com o suporte de geotecnologias e modelo predictivo. Estudos Geográficos. Rio Claro/SP, 5 (1). P. 63-86. 2007.

PEDRO, F.G; LORANDI, R. Potencial natural de erosão na área periurbana de São Carlos-SP. Revista Brasileira de Cartografia. Rio de Janeiro, nํ5 56/01, p. 28-33. 2004.

PETSCH, C; ZUCCHI, V. P.; BRAVO, J. V. M.; BUENO, M. B; MINAKAWA, N. da S. Elaboração das Cartas de Suscetibilidade e Potencialidade à Erosão Laminar em Douradina, Estado do Paraná. Revista Brasileira de Geografia Física. $n^{\circ} 02, p$. 400-411. 2012.

PINTO, S.A.F. Sensoriamento Remoto e Integração de Dados Aplicados no Estudo da Erosão dos Solos: Contribuição Metodológica. 1991. $147 \mathrm{f}$. Tese (Doutorado em Geografia). Faculdade de Filosofia, Letras e Ciências Humanas, Universidade de São Paulo. São Paulo, 1991.

PINTO, S.A.F. Contribuição Metodológica para Análise de Indicadores da Erosão do Solo Utilizando técnicas de Sensoriamento Remoto, Geoprocessamento e Modelo Predictivo. 1996. 136 f. Tese (Livre Docência). Instituto de Geociências e Ciências Exatas, Universidade Estadual Paulista Júlio de Mesquita Filho. Rio Claro. 1996.

ROSSETTI, L.A.F.G. Geotecnologias aplicadas à caracterização e mapeamento das alterações da cobertura vegetal intra-urbana e da expansão urbana da cidade Rio Claro (SP). 2007. 115 f. Dissertação de Mestrado (Mestrado em Geografia). Universidade Estadual Paulista/ Rio Claro. Instituto de Geociências e Ciências Exatas, Rio Claro, 2007.

RUTHES, J. M.; TOMAZONI, J. C.; GUIMARÃES, E.; GOMES, T. C.; Propriedades do Solo da Bacia Hidrográfica do Rio Catorze que Intensificam a Erosão Laminar. Revista Brasileira de Geografia Física. V. 01, pag. 160-169. 2012.

SALOMÃO, F.X. de T. Controle e prevenção dos processos erosivos. In: GUERRA, A.J.T.; SILVA, A.S. BOTELHO, R.G.M. (orgs.). Erosão e Conservação dos Solos: conceitos, temas e aplicações. $2^{a}$ ed. Rio de Janeiro: Bertrand Brasil. p. 229- 267. 2005.

SANTOS, R.D. dos; LEMOS, R. C. de. SANTOS, H. G. dos; KER, J.C; ANJOS, L.H.C. Manual de descrição e coleta de solo no campo. Viçosa: Embrapa, 2005. 100 p. 
SILVA, A. S. da. Análise morfológica dos solos e erosão. In: GUERRA, A.J.T.; SILVA, A.S. BOTELHO, R.G.M. (orgs.) Erosão e Conservação dos Solos: conceitos, temas e aplicações. $2^{\underline{a}}$ ed. Rio de Janeiro: Bertrand Brasil. p. 101-126. 2005.

SILVA, A. M.; SCHULZ, H. E.; CAMARGO, P. B. Erosão e hidrossedimentologia em bacias hidrográficas. São Carlos: RiMa. 2004.

VENIZIANI JUNIOR, J.C.T. Utilização de índices de vegetação para estimativa da proteção do solo pela cobertura vegetal: uma contribuição para o uso da equação universal das perdas de solo. 2003. $137 f$. Dissertação de mestrado (Mestrado em Geografia). Universidade Estadual Paulista/ Rio Claro. Instituto de Geociências e Ciências Exatas, Rio Claro, 2003.

(Recebido em 29.05.2015; Aceito em: 11.05.2016) 